direct payments, but receive substantial program benefits through import restriction, marketing regulations, and price supports, according to UC Davis agricultural economist Daniel Sumner.)

While the new farm bill ends the budget assessment on dairy producers, it phases out over 4 years government support for butter, powdered milk and cheese, replacing it with a loan program. Producers of wheat, feed grains, cotton and rice can receive "market transition" payments for 7 years.

"The impact on dairies will be gradual and therefore minimal," says L.J. "Bees" Butler, UC Davis agricultural economist. "It gives people time to adjust. We may eventually see co-ops putting production quotas on producers."

Export subsidies and import barriers remain in place. The Dairy Export Incentive Program remains fully funded until 2002.

The Secretary of Agriculture will consolidate the 33 federal milk marketing orders to between 10 and 14 over 3 years. However, California is authorized to continue its marketing order, including milk standards and pooling provisions.

The 1996 Farm Bill guarantees annual fixed but declining payments to wheat, feed grains, cotton and rice growers, rather than the deficiency payments that have historically varied with market prices. It places a $\$ 36$ billion cap on payments over the next 7 years. Under the old system, farm subsidies would increase dramatically whenever market prices fell. Marketing loan programs will continue with a cap on loan rates for rice, wheat, feed grains, soybeans and other oil seeds and cotton.

Overall the revised farm bill's effect on California will be relatively small, says Sumner, UC Davis economist, because its agricultural industry is less dependent on these federal subsidies than other states.

The Market Promotion Plan has been authorized at $\$ 90$ million and renamed the Market Access Plan. The news here was that the Farm Bill didn't kill the controversial program, Sumner says. The program, which was created to stimulate agricultural exports, is considered by urban interests to be corporate "pork," he says.

The 1996 Farm Bill, also known as the Federal Agriculture Improvement and Reform (FAIR) Act, was initially part of Congress' effort to trim the federal budget, but how much will be saved? Sumner says its hard to tell because the numbers are projections.

"The FAIR act is very likely to cause outlays under basic farm programs and related activities of about $\$ 47$ billion," Sumner explains.
"Last year, when the FAIR was being developed, the Congressional Budget Office (CBO) projected the 1990 Act to cost about $\$ 49$ billion, but some other analysts have said their models suggest that the 1990 Act would have cost less than $\$ 40$ billion over the next 7 years.

"So you could argue that FAIR saved $\$ 2$ billion (as it is scored by CBO) or you could say it will probably cost several billion more than the 1990 Act." (Projected savings plummeted during the drafting of the bill because market prices rose; the initial 7-year cost estimate of the 1990 Farm Bill had been $\$ 57$ billion.)

Although the 1996 Farm Bill calls for significant changes, it does not end farm subsidies in 2002 , says Sumner. "It doesn't say subsidies will drop to zero," he explains. "I think it's unlikely the United States will eliminate farm programs completely in the year 2002, but that depends on the state of policy and politics in 2001."

Anyone who has enrolled in the program or maintained a crop acre base in the last 5 years can sign up for the 7-year contract from May 20 through July 12 .

The 1996 Farm Bill also:

- Establishes a new $\$ 35$ million program for purchasing 170,000 to 340,000 acres of "prime and unique" farmland to limit nonagricultural use of the land.

- Establishes the new environmental quality incentive program authorized at $\$ 200$ million annually, to help crop and livestock producers make environmental and conservation improvements on the farm.

- Reauthorizes federal research programs for 2 years while Congress continues its review.

- Authorizes $\$ 300$ million for the Fund for Rural America for 3 years.

- Reauthorizes through 2002 the Conservation Reserve Program with up to 36.4 million acres of erodible land.

\section{Putah Creek update}

In the Nov.-Dec. 1995 issue of California Agriculture, we reported that lawsuits had been filed to establish rights to the waters of Putah Creek after water diversions for urban and agricultural use caused the lower Putah Creek to dry out and large numbers of its fish to die in 1989. After 6 years of litigation, a Superior Court judge in Sacramento ruled to increase water flows to the creek by about 10,500 acre feet a year roughly a $50 \%$ increase over the current release schedule. Plaintiffs had asked that flows be increased by 30,000 acre feet per year. 